УДК : 327.57:316.4/.7]:[172.4.022.1:005.336](430)(045)

\title{
ФОРМУВАННЯ ПОЗИТИВНОГО КУЛЬТУРНОГО ІМІДЖУ КРАЇНИ (НА ПРИКЛАДІ НІМЕЧЧИНИ)
}

\section{Дзюба Олег Андрійович}

Народний артист України, професор,

Київський національний університет культури і мистецтв, м. Київ, Україна

ORCID: 0000-0002-2125-1103

olegd@i.ua
Надіслано:

05.02.2020

Рецензовано:

28.02.2020

Прийнято:

03.03.2020

Нині, в епоху глобалізації, світових економічних криз і конкуренції між державами за лідерство в регіоні чи навіть у світі, питання позитивного іміджу стає актуальним як ніколи, наповнюється новим сенсом, і всебічно використовується державами. Не існує зараз у світі країни, яка б не приділяла увагу тому, яке уявлення про неї мають у світі, тим можливостям, які відкриває для неї «м'яка сила» привабливості й позитивного іміджу. Адже саме позитивний імідж держави сприяє надходженню до країни інвестицій, впливає на міжнародну підтримку, дає можливість досягнути зовнішньополітичних цілей і захистити національні інтереси. Існувати ізольовано в сучасному глобалізованому світі окрема країна не може. Ізоляція приводить до припинення розвитку будь-якої сфери - від економіки до культури чи освіти, тобто імідж країни (держави) - це стратегічно важлива характеристика.

Підхід до формування іміджу країни (держави) повинен бути комплексним. Інформаційна складова - один з найважливіших елементів цього комплексу. Сучасні інформаційні технології розвиваються шаленими темпами та стають все більш вагомими у нашому житті, іноді вони можуть стати тим ресурсом, який дозволяє показати з вигідного боку досягнення у будь-якій сфері, або ж перетворитися на інформаційну зброю. Імідж держави залежить саме від інформації та оцінки її ззовні та 3 середини країни. Зокрема, інформаційна політика створює умови для належної присутності держави на світовій арені.

У статті розглянуто поняття «імідж країни», «імідж держави», з яких елементів вони складаються; що таке зовнішній та внутрішній імідж, його вплив на цільову аудиторію на прикладі формування іміджу Німеччини, яка спромоглася за невеликий (в історичному сенсі) проміжок часу, з країни, яку вважали агресором, винним у загибелі мільйонів людей, країною, яка розв’язала Другу світову війну, покращити свій імідж до найпривабливішої у світі країни, яку поважають на міжнародній арені, якою пишаються мешканці 
в середині, та яку розглядають як країну № 1, в якій мріють жити тисячі емігрантів.

Ключові слова: імідж країни, елементи іміджу, фактори формування іміджу, бренд держави, міжнародний імідж країни, м'яка сила, цільова аудиторія, інформаційні ресурси держави, рейтинг; засоби масової інформації.

Dziuba Oleg, People's Artist of Ukraine, Professor, Kyiv National University of Culture and Arts, Kyiv, Ukraine

\section{Formation of the Country's Positive Image on the Example of Germany}

Nowadays, in an age of globalization, global economic crises and competition between states for leadership in the region or even in the world, the issue of positive image is becoming more relevant than ever, filled with new meaning, and is being used extensively by states. Now there is no country in the world that does not pay attention to what its conception is in the world, the opportunities that open to it the "soft power" of attractiveness and positive image. After all, it is the positive image of the state that contributes to the flow of investment into the country, influences international support, gives the opportunity to achieve foreign policy goals and protect national interests. A single country cannot exist in isolation in today's globalized world. Isolation leads to the cessation of development of any sphere - from economy to culture or education, i.e. the image of a country (state) is a strategically important characteristic.

The approach to shaping the image of a country (state) should be comprehensive. The information component is one of the most important elements of this complex. Modern information technologies are growing at a rapid pace and are becoming more and more important in our lives, sometimes they can become a resource that allows us to show on the beneficial side of achievements in any field, or turn into an information weapon. The image of the state depends on the information and its assessment from the outside and from the middle of the country. In particular, information policy creates the conditions for a proper state presence on the world stage.

The article deals with the notions of "image of the country", "image of the state", what elements they consist of; what is the external and internal image, its influence on the target audience by the example of the formation of the image of Germany, which has succeeded in a small (in historical sense) period of time, from a country which was considered to be the aggressor responsible for the deaths of millions of people, a country that has solved the Friend to improve its image to the most attractive country in the world, respected in the middle of the international arena, and regarded as the No. 1 country in which thousands of emigrants dream of living. 
Міжнародні відносини: теоретико-практичні аспекти

Випуск 5 (2020)

ISSN (print) 2616-745X; ISSN (online) 2616-7794

Key words: country's image; image elements; image forming factors; state's brand; international country's image; soft power; target audience; state information resources; rating; media.

Дзюба Олег Андреевич, Народный артист Украины, профессор, Киевский национальный университет культуры и искусств, г. Киев, Украина

\section{Формирование позитивного культурного имиджа страны (на примере Германии)}

Сейчас, в эпоху глобализации, мировых экономических кризисов и конкуренции между государствами за лидерство в регионе или даже в мире, вопрос положительного имиджа становится актуальным как никогда, наполняется новым смыслом и всесторонне используется государствами. Нет сейчас в мире страны, которая не уделяла бы внимание тому, какое представление о ней имеют в мире, тем возможностям, которые открывает для нее «мягкая сила» привлекательности и положительного имиджа.

Ведь именно положительный имидж государства способствует поступлению в страну инвестиций, влияет на международную поддержку, дает возможность достичь внешнеполитических целей и защитить национальные интересы. Существовать изолированно в современном глобализированном мире отдельная страна не может. Изоляция приводит к прекращению развития в любой сфере - от экономики до культуры или образования; то есть имидж страны (государства) - это стратегически важная характеристика. Подход к формированию имиджа страны (государства) должен быть комплексным. Информационная составляющая - один из важнейших элементов этого комплекса. Современные информационные технологии развиваются бешеными темпами и становятся все более весомыми в нашей жизни, иногда они могут стать тем ресурсом, который позволяет показать с выгодной стороны достижения страны в любой сфере, или же превратиться в информационное оружие. Имидж страны зависит именно от информации и оценки ее снаружи и изнутри. В свою очередь, информационная политика создает условия для надлежащего присутствия государства на мировой арене.

В статье рассмотрено понятие «имидж страны», «имидж государства», из каких элементов они состоят; что такое внешний и внутренний имидж, его влияние на целевую аудиторию на примере формирования имиджа Германии, которая смогла за небольшой (в историческом смысле) промежуток времени, из страны, которую считали агрессором, виновным в гибели миллионов людей, развязавшим Вторую мировую войну, улучшить свой имидж. Германия сейчас самая уважаемая страна в мире, с которой считаются на международной арене. 
Ей гордятся ее жители, и тысячи эмигрантов рассматривают как страну № 1 для жизни.

Ключевые слова: имидж страны; элементы имиджа; факторы формирования имиджа; бренд государства; международный имидж страны; мягкая сила; целевая аудитория; информационные ресурсы государства; рейтинг; средства массовой информации.

\section{Вступ}

Аналіз формування іміджу Німеччини (від негативного до найкращого у світі) та інших країн, які досягли певного успіху в окремій галузі (або, чому їх зусилля виявилися марними) може служити прикладом створення позитивного іміджу України. На тлі сучасних політичних перепетій та іміджевих втрат Україні конче потрібно працювати над створенням свого позитивного іміджу, який певною мірою допоможе досягнути успіху у конкурентній боротьбі держав на політичній та економічній арені в епоху нестабільності, військового конфлікту, економічних криз та світової глобалізації.

\section{Аналіз останніх досліджень і публікацій}

Питання створення та вдале використання іміджу країни досліджуються у роботах багатьох науковців, серед яких: Л.Губерський, Г.Лавриненко, Г. Почепцов, М. Сенченко, Є.Тихомирова, Ю.Чала та інші, в яких даються іміджеві рекомендації Україні і моделюються варіанти розвитку стосунків між державами на основі міжнародних рейтингів.

\section{Формулювання мети і завдань статті}

3 огляду на необхідність формування і підтримки позитивного іміджу України в сучасному світі автор вважає за потрібне дослідити та проаналізувати приклади створення іміджу у провідних країнах світу, особливо у Німеччині, яка може похвалитися неабиякими досягненнями у цій галузі.

\section{Виклад основного матеріалу дослідження}

Що таке імідж країни або держави? Його можна визначити як образ уявлення про країну (державу), сформований в індивідуальній, груповій, або масовій свідомості громадян як самої країни, так й інших держав у результаті тривалого процесу взаємодії різних факторів.

«Імідж держави», або «державна маска» - це поняття відоме нам ще за часів Ніколо Макіавеллі (Brown, 2001, p.5). Створення іміджу, по-перше, це обробка певного початкового матеріалу для зменшення негативних властивостей і посилення позитивних, по-друге, - це ідеальна модель, яку накладають на оброблений матеріал, по-третє, це неминучі викривлення, які вносяться засобами його передачі і тиражування (наприклад, засобами 
масової інформації), на останок, це власне сприйняття іміджу цільовою аудиторією, а також окремої людини, яка у своїй свідомості створює власний імідж на основі нав'язаної моделі, але з урахуванням особистого уявлення (Akayomova, 2010, p. 54).

Сформований міжнародний імідж держави $є$ перш за все результатом її цілеспрямованої діяльності, що проводиться в політичній, економічній, соціальній, культурній, освітній та інших сферах, і розповсюдження позитивних досягнень країни- держави у світовій спільноті.

На думку дослідників, треба розрізняти поняття «імідж країни» та «імідж держави». Вони іноді збігаються, але не є тотожними.

Насамперед, «держава» спирається на політичну складову, а «країна» на культурну та соціально-економічну.

Зазвичай поняття «держава» й «країна» в сучасному світі мають майже те ж саме значення; але слово «держава» може бути вужчим за поняття «країна» і позначати не всю територію, на якій проживає «та чи інша політично організована соціальна спільність», а «країни» не завжди можуть називатися державами (наприклад, Україна XIX ст. була країною українців, але не мала державності: була поділена між Австро-Угорщиною та Росією; зараз Крим, окупована частина Донбасу та Луганщини - це наша країна, але наші державні установи не мають влади на цих територіях).

Політичний імідж держави - явище складне за структурою, складається 3 багатьох компонентів. Політологи, соціологи та політичні іміджмейкери називають наступні елементи структури політичного іміджу держави:

- суб'єктивні - імідж політичного лідера, імідж політичної еліти, імідж політичних інститутів влади, імідж політичних партій, що перебувають при владі, та опозиційних, імідж збройних сил, імідж дипломатів;

- об'єктивні - іміджі: політичного режиму, рівня демократії, соціальноекономічного розвитку, законодавчих і судово-виконавчих, релігійних стосунків, зовнішньополітичних акцій;

- часові - культурно-історичні факти, сучасні політичні події, політичні прогнози;

- комунікативні - модель іміджу, канали трансляції та тиражування, цільова аудиторія (Danilov, 2009, р. 18).

Імідж країни формується протягом тривалого часу на основі географічного положення, клімату, релігії, культури та традицій населення та ін. Тобто на основі майже незмінних характеристик.

Імідж держави, навпаки, створюється досить швидко, спирається на умовно динамічні фактори: на політично-правову систему країни, показники економічного розвитку, ступені свободи та ін. 
Від політики держави та сприйняття цієї політики суспільством залежить, чи будуть збігатися поняття «імідж країни» та «імідж держави».

Сучасний світ, звичайно, розрізняє Німеччину часів кайзера Вільгельма, при якому була розв'язана Перша світова війна, німецьку державу часів Гітлера, та німецьку країну, де народилися і створювали шедеври Гете, Шиллер, Вагнер, Ремарк.

Імідж держави та імідж країни як складові їі «м'якої сили», впливають на конкурентоспроможність держави на світовій арені.

Умовно складові елементи іміджу країни можна поділити на внутрішні, які на відміну від атрибутів (ім'я, назва країни, герб, прапор, гімн, що $є$ постійними), мають змінний характер: добробут населення; дотримання конституційних прав кожного громадянина; рівень освіти населення; рівень зайнятості населення; рівень корупції; рівень злочинності; рівень тіньового сектору економіки; соціальне самопочуття; рівень охорони здоров'я; тривалість життя; рівень соціалізації населення; розмір і склад «споживчого кошика; рівень свободи засобів масової інформації, тощо.

I зовнішні фактори іміджу: макроекономічна стабільність; права кожного громадянина; зовнішня політика країни; національні інтереси та пріоритети; якість трудових ресурсів; інфраструктура; темпи росту національних ринків; конкурентоспроможність компаній; членство в міжнародних організаціях; розвиненість фінансового ринку; розвиток відносин зі стратегічними партнерами; якість нормативно - правового регулювання; інвестиційний клімат; технологічний рівень; інноваційний потенціал.

Внутрішній імідж країни - це привабливість держави, як основного місця проживання, гордість за країну, бажання в ній жити, захищати, щастя, комфорт та планування свого майбутнього у цій країні .

Зовнішній імідж це - цікавість країною, бажання приїхати до неї, робити у ній бізнес та вкладати кошти, комфорт і безпека.

Зовнішній імідж формують ЗМІ, історія, традиції, особисті враження окремих осіб. Часто імідж країни асоціюється 3 іменами сучасних або історичних відомих людей, діячів культури та спорту.

Створення іміджу держави вимагає постійної роботи, над ним потрібно працювати, як і над іміджем людини. Імідж напрацьовується роками, втрачається миттєво.

Дотримання світових стандартів, які розроблені й визнані світовою спільнотою, закріплені у нормах міжнародного права, є важливими чинниками міжнародного іміджу держави. Світові стандарти відстежуються міжнародними організаціями, рейтинговими агенціями, вони дають порівняльну оцінку розвитку економіки та державного управління, рівню корупції, рівню демократії, добробуту, якості життя, прав людини, свободи преси, тощо у всіх 
країнах світу. Світові рейтинги формують імідж країни на міжнародній арені. До найважливіших рейтингів, або індексів, належать:

- The Global Competitiveness Index - Індекс глобальної конкурентоспроможності (один з найбільш відомих світових індексів, який щорічно складається Всесвітнім економічним форумом (ВЕФ) у Давосі (Швейцарія));

- Corruption Perceptions Index (CPI) - Індекс сприйняття корупції (ICK) (щорічно розраховується міжнародною організацією Transparency Internetional);

- Index of economic freedom - Індекс економічної свободи (щорічно розраховується Wall Street Journal i Heritage Foundation для більшості країн світу з 1995 року); та інші (Shevchenko, 2008, Issue 79, Part 1).

Вкладення коштів у покращення іміджу держави вважаються стратегічними у будь- якій країні світу:

- США витрачає приблизно 1,4 млрд дол. щорічно на розробку public policy і формування позитивного іміджу Америки за кордоном;

- Велика Британія та Німеччина витрачають приблизно по 1,2 млрд дол. на створення свого позитивного іміджу;

- Саудівська Аравія, щоб створити імідж надійного партнера, витрачає 6 млрд. доларів на рік;

- Росія витратила 40 млн. доларів на створення англомовного каналу Russia Today, 10 млн доларів витратив уряд Росії за 2,5 роки на послуги PR агентств у Вашингтоні;

- Північна Ірландія витрачає приблизно 6,5 млн фунтів;

- Китай - 6 млрд дол.

Україна в 2009-2011 рр. витрачала по 230 млн. гривень. У 2017 р. було витрачено 77 млн, 2018 року на 70 млн грн зросла фінансова підтримка «забезпечення міжнародного позитивного іміджу України» та діяльності Українського інституту - створеної у 2017 році інституції з презентації України за кордоном, вона склала трохи більше 147 млн грн.

Найважливішою характеристикою іміджу держави іміджмейкери та дослідники вважають його функціональність. Тобто створення певного іміджу держави не має бути самоціллю. Насамперед, створюючи імідж, ми намагаємося досягнути за його допомогою поставлених перед собою цілей.

Свого часу перший канцлер об'єднанних німецьких земель під назвою ФРН К. Аденауер поставив перед частиною країни, яка після Другої світової війни була окупована, вщент зруйнована і не мала державності, дуже амбітні цілі:

1. забезпечення економічної і політичної побудови нової держави;

2. військова безпека;

3. возз'єднання відторгнутих частин Німеччини (Hakke, 1995, pp. 217-220). 
За історично невеликий проміжок часу (з 1945 р. і до сьогодення) Об'єднана Німеччина стала лідером ЄС, має найвищий економічний рейтинг у світі (рейтинги центру маркетингових досліджень Costumer Research North America і консалтингової фірми Simon Anholt.) і виступае гарантом світовою стабільності і безпеки (поряд із Францією веде перемовини у Мінську стосовно україно-російського конфлікту)

Німеччина завжди прагнула стати світовим лідером. Того, що вона не змогла досягти, застосовуючи «тверду силу» - розв'язанням Першої та Другої світових війн, вона досягла завдяки «м'якій силі».

У сучасних міжнародних відносинах Німеччина вважається країноюлідером. Для того, щоб нівелювати негативне ставлення до країни у світі після Другої світової війни та створити свій новий позитивний міжнародний імідж, Німеччині потрібно було прикласти чимало зусиль. Міжнародний імідж сучасної Німеччини складався протягом тривалого часу в результаті взаємодії різних факторів, це і міжнародний авторитет, і ступінь впливу на світову політику та економіку та ін. Сьогодні Німеччина - провідна країна Європейського Союзу і їі голос є вирішальним у прийнятті важливих рішень членами ЄС. У німецької економки найвищий рейтинг у світі, тепер Німеччина вирішує долю не тільки своєї національної економіки, але й економік усього Європейського Союзу. Важливим фактором міжнародного іміджу сучасної країни виступають особливості становлення і розвитку німецької держави.

Після Другої світової війни, враховуючи попередній історичний досвід, європейські держави-переможниці, особливо Франція, були зацікавлені в тому, щоб включити «потенційно небезпечну», з їх точки зору, частину Німеччини Федеративну республіку - в таку міжнародну систему, яка дозволяла б у будьякий час контролювати можливі нові спалахи націоналістичних прагнень свого «історично небезпечного» сусіда.

Німеччина ж, зі свого боку, повинна була прийняти всі пропозиції в напрямку європейської інтеграції. Лише згода на таку інтеграцію давала їй реальний шанс позбуватися дискримінації та опіки союзників у зовнішньополітичних відносинах i розраховувати у майбутньому стати рівноправним партнером європейської спільноти.

Для німецької країни, розділеної між Сходом і Заходом (НДР та ФРН), ніякої спільної зовнішньої політики, зрозуміло, бути не могло. «Залізна завіса» відділяла Східний блок, в якому панував СРСР, від Заходу. Кордон, поділивши Німеччину на 40 років, вважався найнепрозорішим у світі. НДР проводила радянську політику і майже не мала змоги для маневрів на світовій арені (Pavlov, 1998, p 227) 
У цій статті буде розглянуто поступову зміну іміджу саме ФРН, бо нинішня Німеччина продовжує ті принципи і користується методами, які були закладені політичними лідерами Західної Німеччини.

Головним зовнішньополітичним завданням для канцлера ФРН Конрада Аденауера (перший канцлер Західної Німеччини (1949-1963)) було «запобігання зовнішньополітичної ізоляції Федеративної республіки». Він хотів інтегрувати ФРН в європейську та євроатлантичну систему, що, з одного боку, давало безпеку самій країні, а 3 іншого - убезпечувало європейських сусідів від неї самої.

К. Аденауер чітко, ясно й просто сформулював напрямки німецької зовнішньої політики. Федеративна республіка Німеччини повинна знову стати визнаним і рівноправним партнером західних країн. Аденауер прагнув якомога міцніше інтегрувати Німеччину в систему відносин між державами Заходу. Без такої інтеграції, вважав Аденауер, ФРН може стати жертвою радянської силової політики.

Тому Федеративна республіка Німеччини поступово ставала членом ряду європейських організацій. 1951 р. вона стала однією з держав-засновників Європейського об'єднання вугілля і сталі (ЄОВС) - своєрідного прообразу Євросоюзу. 1955 року, зі вступом у силу Паризьких угод, підписаних 23 жовтня 1954, для ФРН закінчився період окупації, переборюючи опір політичних супротивників, вона стала членом НАТО.

1957 р. ФРН стала членом Європейського економічної спільноти (ЄЕС). 1973 р., одночасно з НДР, ФРН була прийнята в Організацію Об'єднаних Націй. Зокрема, Східна частина Німеччини - Німецька Демократична Республіка, яка була створена як держава прорадянської орієнтації, стала одним із засновників Ради економічної взаємодопомоги (РEB) 1949 р., Організації Варшавського договору 1955 р. На той час ФРН вже була вже визнана більшістю держав капіталістичного світу, а НДР - тільки комуністичними урядами.

у 1952 р. разом із Бельгією, Францією, Італією, Люксембургом та Нідерландами Федеративна Республіка Німеччини заснувала Європейське об'єднання вугілля і сталі (ЄОВС); а 1957 р. - Європейську економічну спільноту (ЄЕС) та Європейську спільноту з атомної енергії (Євроатом). Завдяки договору про злиття у Європейські спільноти (ЄС) від 1965 року були створені єдині органи управління для ЄОВС, $Є \mathrm{EC}$ і Євроатому. При цьому переслідувалася мета підвищити політичну вагу Європейської ради та Європейської комісії та впорядкувати діяльність спільних органів ЄС.

Споруда Берлінської стіни 1961 р. за ініціативою Східної Німеччини посилила протистояння між двома німецькими державами. Наростало протистояння й у світі. В епіцентрі розколу між двома різними світоглядами, етичними цінностями та політичними завданнями опинилася Німеччина. 
Канцлер Аденауер твердо вирішив, що Німеччина не може бути нейтральною. У єдності з Заходом канцлер бачив не тільки розв'язання проблеми безпеки, але й вирішення питання об'єднання країни. ФРН була готова брати участь в обороні Заходу і це дало їй шанс досягнути своєї мети не тільки в оборонній сфері, а також досягнути економічної стабільності та політичного рівноправ'я серед країн Заходу.

К. Аденауер завжди був противником будь-якого компромісу з комуністичною ідеологією та радянською системою господарювання. Німеччину виключно бачив інтегрованою у західний світ. Все ж визнаючи, що без згоди Радянського Союзу вирішення німецького питання неможливе, Аденауер як політик і дипломат розумів необхідність поліпшення іміджу ФРН вголовній країні протилежного ідеологічного табору, він пішов на встановлення дипломатичних, а потім і торговельно-економічних відносин 3 СРСР (Pavlov, 1998).

Міжнаціональна ворожнеча століттями роз'єднувала непримиримих сусідів - Німеччину та Францію. Вінцем дипломатичної кар'єри Аденауера став січень 1963 р., коли лідери двох країн підписали угоду про дружбу. У Аденауера склалися добрі відносини із президентом Франції Шарлем де Голлем. «Не забувайте, - говорив Аденауер, - що я - єдиний німецький канцлер, який понад усе ставить єдність Європи, а вже потім інтереси своєї власної держави. Яготовий пожертвувати німецьким возз'єднанням, якщо ми створимо і увійдемо в сильний західний табір. У взаєморозумінні між Німеччиною та Францією знаходиться європейське майбутнє». У 1961 р. Аденауер говорив: «Наша мета, щоб у майбутньому Європа стала єдиним домом для всіх європейців, щоб вона стала житлом волі». Майбутнє Європи канцлер бачив у поєднанні економік, у постійному обміні духовними і культурними цінностями.

Наприкінці 40-х та початку 50-х рр. молодь захопила ідея побудувати нову Європу без державних кордонів, без суперництва між країнами, вільну і доступну. Це була ідея союзу спочатку західноєвропейських держав, який потім повинен розширюватися, охопити всі країни Європи і стати третьою силою у світі.

Для Німеччини об’єднана Європа була шляхом отримання більшої національної самостійності, незалежності та впливовості, на відміну від Франції або Англії, які у разі об’єднання поступалися частино своїх національних інтересів і суверенних прав.

ФРН заради створення нового іміджу не відмовилась, але відклала і віднесла на другий план свої ідеї об'єднання Німеччини (замінила ідею застосування «твердої сили» на «м'яку»), і зосередилась на спільній діяльності у міжнародних організаціях, в яких брала активну участь. Керівництво ФРН зосередилось на формуванні позитивного іміджу розвинутої, відкритої світу 
і налаштованої на співпрацю країни. Привабливий зовнішньополітичний імідж став важливим інструментом для об'єднання країни.

Між двома німецькими державами взаємовідносини покращилися лише 1969 року., з приходом на пост канцлера ФРН Віллі Брандта, який ініціював так звану «східну політику», тобто політику нормалізації відносин 3 країнами прорадянської орієнтації. У 1972 р. ФРН та НДР підписали договір про основи взаємовідносин, визнавши одна одну. У серпні 1990 р. ФРН та НДР уклали договір про об'єднання Німеччини. Переговори про згоду на об'єднання з боку СРСР і союзних держав, що отримали назву переговорів за схемою «2+4», завершилися підписанням договору про остаточне врегулювання «німецького питання». Договір був підписаний у вересні 1990 р. міністрами закордонних справ шести країн і ратифікований у березні 1991 p.

Проблему зруйнованого іміджу Німеччини у післявоєнні роки та створення нового було вирішено завдяки побудові нових міжнародних відносин, які базувалися на необхідності співпраці Німеччини 3 іншими країнами.

ФРН як більш успішна і в політичному, і економічному відношенні держава, а також завдяки побудові позитивного іміджу шляхом планомірної інформаційної роботи, змогла успішно виконати свою «стратегічну задачу по досягненню єдності німців на західнонімецьких умовах» (Patrushev, 2003, p. 22).

Наперекір певним труднощам, німці все більше усвідомлюють себе єдиною нацією, якій є чим пишатися.

Роль Німеччини в міжнародній політиці, її імідж провідної країни світу базуються, перш за все, на основі їі економічної потужності. Тільки в період 3 1950 року по 1963 рік промислове виробництво в країні зросло майже у два рази, значно скоротилося безробіття. Цей період увійшов в історію, як «економічне диво» Німеччини (Pavlov, 2005, p. 411).

Уже з початку 1970-х рр. ФРН стала надавати фінансово-технічну допомогу іншим країнам світу. Зараз ФРН - один з найпотужніших донорів і інвесторів країн ЄC, «локомотив» світової економіки.(Наприклад, Німеччина третій за розміром внесків донор 0ОН. Ї̈̈ частка у бюджеті цієї організації 10 \%, нагадаю, ООН об’єднує 193 країни світу).

Об'єднана Німеччина займає у світі:

- за чисельністю населення - 16 місце (82,8 млн чол.);

- по виробництву ВНП - 3 місце (після США і Японії);

- по експорту - 2 місце (після США);

За обсягом експорту ФРН значно випереджає провідні країни світу, в т. ч. Францію, Англію, Японію і США. Головними імпортерами німецьких товарів є країни ЄС. На другому місці - США. 
Німеччина нині входить до міжнародного клубу найрозвиненіших країн світу - «G-7» - за рівнем економічного розвитку та величині економічного потенціалу, частці у світовому виробництві, ступенем залучення до міжнародного розподілу праці та ін.

Німеччина - лідер на багатьох світових ринках готової продукції.

Найбільш конкурентоспроможними галузями німецької промисловості є:

- автомобілебудування;

- транспортне машинобудування (вагонобудування, літакобудування);

- загальне машинобудування (виробництво верстатів, різних приладів);

- електротехнічна промисловість; точна механіка і оптика; хімічна, фармацевтична і парфумерно-косметична промисловість;

- чорна металургія.

Ці галузі мають ряд переваг для успішної зовнішньоекономічної, експансії. Зокрема, це:

1. висока якість виробництва та широкий асортимент виробів;

2.використання міжнародних стандартів і водночас готовність виконувати індивідуальні, унікальні замовлення;

3. пунктуальність у виконанні постачання;

4. широка збутова мережа і налагоджене післяпродажне обслуговування, а також відповідність іншим критеріям ринкової конкуренції.

Феномен німецької економіки полягає в тому, що маючи невеликі природні ресурси, країна змогла забезпечити себе сировиною для розвитку своєї переробної промисловості й зосередитись на випуску готової продукції. Цьому сприяли розвинені зовнішньоекономічні зв'язки, тісне інтегрування у світову економіку.

Головна кількість німецьких товарів експортується у сусідні країни держави ЄС. Другим за значенням регіоном збуту німецьких товарів є США. Японія займає порівняно скромне місце

Торговий знак «Made in Germany» в наші дні перетворився на символ високої якості. Так, у 2017 р. німецька компанія Dalia Research представила дослідження національних брендів (Made In Country Index). Згідно 3 отриманими даними, бренд «Made in Germany» зайняв перший рядок рейтингу, отримавши максимально можливі 100 балів (How Germany is perceived in the world). Усе це сприятливо впливає на міжнародний імідж Німеччини, робить країну привабливою для торгівлі, вкладення інвестицій та створює клімат довіри.

Таким чином, створенням нового іміджу Німеччина зобов'язана економіці, яка відіграє значну роль у Європі та в світі. 
Сьоголні Німеччина - це провідна політична сила на Європейському континенті, технологічний лідер в багатьох галузях. Німеччина $\epsilon$ другим за популярністю місцем міграції у світі, поступаючись тільки США.

Головним чинником формування іміджу сучасної Німеччини сьогодні $\epsilon$ впровадження культурної політики як одного з головних компонентів зовнішньої політики. ФРН - одна з небагатьох країн, яка для створення свого позитивного іміджу спирається саме на зовнішню культурну політику. Соціологічні опитування і дослідження як в самій країні, так і за їі межами свідчать про те, що сьогодні саме Німеччина має найпривабливіший внутрішній і зовнішній імідж серед країн Європи. Спираючись на національні інтереси і цінності, Німеччина організовано, систематично і цілеспрямовано формує свій імідж для просування на міжнародній арені своїх інтересів.

Німецькі іміджмейкери розробили напрямки, теми та гасла, які призначені для поширення засобами масової інформації у світі характеризують Німеччину як найпривабливішу країну-бізнес партнера, вагомого політичного гравця, цікавого туристичного об'єкта:

- Німеччина - відповідальний партнер і «локомотив» подальшого розвитку Європейського союзу;

- Німеччина активно виступає за попередження і врегулювання політичних, економічних, екологічних криз і гуманітарних катастроф;

- Німеччина - відкрита світові країна, яка виступає проти расизму та антисемітизму;

- Німеччина - спрямована на майбутнє країни, яка завдяки внутрішнім реформам та інноваціям зробила свою економіку конкурентоспроможною і спирається на колишні досягнення;

- Німеччина - країна ідей і центр перспективних наукових досліджень, що привертає вчених з усього світу і генерує інноваційні імпульси;

- Німеччина - батьківщина всесвітньо відомих художників, музикантів, дизайнерів, архітекторів і спортсменів (How Germany is perceived in the world).

Цільовою групою, як і в повоєнні роки, задля формування міжнародного іміджу ФРН обрала, молодіжну та студентську аудиторію самої країни, так і за кордоном.

«Цілі сучасної зовнішньої політики ФРН в галузі культури та освіти $\epsilon$ прагнення створити образ відкритої світу країни, яка пропонує партнерам можливості для співпраці, з почуттям власної гідності захищає німецькі цінності та позиції в світі, сприяє взаєморозумінню між народами й тим самим робить внесок у справу модернізації та інтернаціоналізації, в тому числі й у самій ФРН» (Lavrynenko, 2011 p. 48)

$\mathrm{y}$ сучасних умовах для досягнення цілей німецькі іміджмейкери віддають перевагу реалізації довгострокових, взаємопов'язаних проектів, 
а не розрізненими заходам 3 короткостроковим ефектом. Важливою особливістю $є$ і залучення якомога більшої кількості інститутів, що діють у сфері зовнішньої політики ФРН.

Одним з таких довгострокових фундаментальних проектів стала іміджева компанія «Німеччина - країна ідей». Вона була прив'язана до чемпіонату світу з футболу 2006 року, проведення якого виграла Німеччина. Великий спортивний захід міжнародного масштабу, привертає увагу ЗМI, як місцевих, так і закордонних, створює суспільний резонанс, дає можливість країні продемонструвати свої досягнення, збільшує потік туристів до країни

Вперше ідею майбутньої потужної іміджевої компанії озвучив у своїй інавгураційній промові канцлер Horst Köhler, він наголосив, що « Німеччина $\epsilon$ країною ідей», яка «заохочує експерименти та допитливість; сміливість, креативність та бажання створювати нове, не забуваючи старі досягнення». Офіційними спонсорами проведення започаткованої канцлером іміджевої кампанії виступив уряд країни: Міністерство економіки та технологій, Міністерство закордонних справ, Міністерство освіти та досліджень, а також Федеральний союз німецької промисловості (BDI). Ї̈̈ бюджет склав 20 млн євро, з яких 10 млн євро надав уряд і 10 млн євро - Федеральний союз німецької промисловості (BDI).

Гасло: «Німеччина - країна ідей», на думку іміджмейкерів, показує німецькі позитивні якості: країна поетів і мислителів, нація науки та культури, нація робітників, яки можуть пишатися брендом «Made in Germany». Для донесення цієї думки були розроблені проекти візуальні проекти, був створений унікальний інформаційний ресурс «Media Service», яким могли скористатися 15 тис. журналістів різних країн, що були акридитовані на чемпіонат світу по футболу. Результат - в друкованих ЗMI, на телебаченні та в інтернеті з'явилося близько 7143 повідомлення про кампанію, які охопили приблизно 471 млн чол.

Розглянемо заходи, які привернули увагу до Німеччини

1 проект: «Ласкаво просимо до Німеччини - країни ідей» («Welcome to Germany - Land of Ideas»).

Реалізація проекту розпочалась 3 жовтня 2005 року в День об'єднання Німеччини. На всіх заходах, присвячених цьому дню, пройшла презентація іміджевої компанії, усі 226 посольств і консульств отримали збірники матеріалів про Німеччину для поширення серед відвідувачів; в аеропортах, на залізничних та автобусних станціях вітали гостей країни.

2 проект: «365». Щороку Німеччина проводиться національний конкурс інноваційних ідей. У ньому беруть участь бізнес-компанії, мистецькі та наукові заклади. Журі обирає 365 цікавих ідей, про кожну з яких будуть розповідати 3МІ кожен 3356 днів року, також виходить щомісячний інформаційний 
Міжнародні відносини: теоретико-практичні аспекти

Випуск 5 (2020)

ISSN (print) 2616-745X; ISSN (online) 2616-7794

бюлетень, а наприкінці року друкують книгу. Конкурс привертає велику увагу громадськості, та потенційних інвесторів.

3 проект: «Алея ідей» («Walk of Ideas»)

За кілька місяців до початку чемпіонату світу в найбільш багатолюдних місцях Берліна були встановлені шість величезних скульптур, що «символізують багатство ідей і винахідницький дух Німеччини».

Установка кожної фігури супроводжувалася увагою ЗМI, що багато в чому пояснювалася сумою проекту (на створення кожної скульптури було витрачено від 300 до 350 тис. Євро) і установкою їх в найбільш багатолюдних місцях міста. «Інноваційні футбольні бутси», Перші футбольні бутси, які допомогли німцям виграти чемпіонат з футболу у 1954 році, бо були оснащені шипами, які допомагали футболістам краще бігати по мокрому і слизькому полю, були створені засновником компанії Adidas німцем на ім'я Adi Dassler.

«Віхи в медицині» - друга скульптура у вигляді гігантської таблетки. Ця скульптура нагадує про те, що найпопулярніша у світі болезаспокійлива таблетка була винайдена в Німеччині компанією Bayer. Німецькі дослідники Felix Hoffmann, Robert Koch, Emil von Behring, Paul Ehrlich and Gerhard Domagk внесли великий вклад в розвиток медицини; У Німеччині були винайдені і вперше застосовані: рентгенівський апарат та серцевий катетер. I в даний час німецькі вчені розробляють близько 300 нових ліків, включаючи вакцину від раку, лікування серцевих нападів, діабету і хвороби Альцгеймера.

«Автомобіль» - ця скульптура була встановлена біля Бранденбурзьких воріт. Увесь світ користується моторами Diesel; популярними у світі є німецькі автомобілі Audi, BMW, Mercedes-Benz, Opel, Porsche i Volkswagen; завдяки німецьким дослідникам в автомобілях з'явилися подушки безпеки, ABS, ESP, повний привід і ще багато чого.

«Сучасне книгодрукування» - скульптура нагадує про те, що друкарський станок був винаходом німця Гутенберга. Друкарський станок дав змогу поширити перший у світі бестселер - Біблію, що прискорило процеси Реформації та Просвітництва. Німеччина дала світові великих письменників і мислителів - Гете, Шиллера, Манна, Братів Грімм та ін.

«Музичні шедеври», підкреслює величезний внесок німецьких композиторів у створенні всесвітньо відомих шедеврів музики - весільний марш Мендельсона, симфонії Бетховена, етюди Шумана, токати Баха i «Політ Валькірії» Вагнера.

«Теорія відносності», яка була створена німцем Альбертом Ейнштейном, що призвело до розвитку квантової механіки і лазерів науковцем Theodor Hänsch, який 2005 року отримав Нобелівську премію 3 фізики, (а також $\epsilon$ нагадуванням про те, що німецька нація позбавлена антисимітизму). 
Проект «Алея ідей» з'явився одним 3 найуспішніших в іміджевої кампанії, оскільки креативно виконані скульптури привернули величезну увагу з боку журналістів, населення і туристів.

4 проект: 100 видатних умів майбутнього («100 Masterminds of Tomorrow») це логічне продовження попереднього проекту «Алея ідей». 100 особистостей, яких відібрало журі, $є$ продовжувачами великих звершень Німеччини у минулому, вони досягли неабияких успіхів у рвізних галузях науки, бізнесу, мистецтва. На виставці, присвяченій досягненням цих людей, були представлені їхні фото, біографії та, головне - їхні ідеї.

5 проект: «Інвестуй в Німеччину - країну ідей». Мета проекту представити Німеччину як найкращу країну для ведення бізнесу. Для цього залучили різноманітні засоби: від розповсюдження інформаційних брошур про привабливий інвестиційний клімат і можливості країни до провокативної рекламної кампанії за участю оголеної німецької моделі, загорнутої лише у стяг Німеччини, Клаудії Шифер. Ця рекламна кампанія охопила майже увесь світ. Такі плакати, які відрізнялись хіба що ступенем оголеності красуні (у мусульманських країнах вона була більш одягнутою) викликали емоційну реакцію по всьому світу і жваве обговорення у ЗМІ різних країн.

Успішно реалізовані проекти мали на меті переконати світ і потенційних інвесторів, що у Німеччині реалізуються усі гарні ідеї.

Цікаво, що по закінченню чемпіонату світу, де чемпіонський титул здобула Італія, світові ЗМІ майже в один голос стали говорити про те, що на цьому чемпіонаті було два переможці - Італія і Німеччина, бо останній вдалося поліпшити свій імідж і вдома, і за кордоном. Дослідження соціологів доводять, що після проведення іміджевої кампанії «Німеччина - країна ідей» більшість німців сприймали свою країну як «прогресивну, космополітичну, вигадливу та інноваційну».

Ця кампанія виявилася настільки успішною, що після закінчення чемпіонату світу, з якою вона була пов'язана, не закінчилась, заходи кампанії «Німеччина - країна ідей», були продовжені ще на 4 роки, до 2010 року!

Заходи іміджевої кампанії охопили величезну аудиторію (за оцінками дослідників) - понад 3,5 млрд чоловік.

\section{Висновки}

Аналізуючи проведення найуспішнішої іміджевої кампанії, можна зробити декілька висновків-рекомендацій:

1. Необхідна логічна послідовність у здійсненні різних частин кампанії, це надає можливості досягнути найбільшого ефекту:

а) створення платформи «Media Service» дало змогу ЗMI всі аспекти проведення кампанії; 
б) обєднання і керівництво фанатами у фан-клубі та конкурс «365» забезпечило підтримку заходам кампанії всередині країни;

в) встановлення скульптур зацікавило не тільки місцеві, але й іноземні 3MI, і залучило велику кількість туристів

2. Держава, працюючи над поліпшенням іміджу, повинна якомога більше залучати суспільство, що забезпечить іміджеву кампанію ресурсами й підтримкою населення.

3. Присутність вищих посадових осіб на о заходах забезпечує увагу ЗМІ і підкреслює зацікавленість держави у розв'язанні проблеми.

4. Своєчасне забезпечення ЗМІ необхідною інформацією (створення «Media Service»), створювання інформаційних приводів (поступова установка скульптур на «Алеї ідей»)

5. Використання англійської мови.

Аналізуючи зусилля, яки доклала Німеччина для створення свого позитивного іміджу, треба звернути увагу на декілька найважливіших моментів, яки стануть у нагоді, країні, яка дбає про свій імідж. По-перше, Німеччина вселяко використовує широку мережу інститутів «м'якої сили» усфері культури, освіти, мови для збільшення своєї привабливості та підвищення іміджу. Серед найбільших інституцій, які працюють на імідж Німеччини, можна виділити Німецьку службу академічних обмінів (DAAD), Службу педагогічного обміну (Pädagogischer Austauschdienst), політичні фонди.

По-друге, це ставлення країни до історії. Німеччина змогла подолати нацистське минуле, ставлення до сучасної країни не спирається на згадку про злочини у війнах. Головне, що покарані нацистські злочинці, а ще Німеччина не намагається замовчати темні сторінки історії, а проводить політику «подолання минулого» («Vergangenheitsbewältigung» або «Aufarbeitung der Vergangenheit»). На практиці це виражається в тому, що Німеччина аж до сьогоднішнього дня виплачує компенсацію постраждалим від Голокосту. Так, до 2015 р. Німеччина виплатила 71 млрд євро жертвам злочинів нацизму. Крім того, відкриті численні музеї, що висвітлюють трагічні події воєнного періоду, наприклад, Єврейський музей в Берліні. У Росії, Польщі, Ізраїлі та США німцям уже майже не дорікають злочинами, скоєними під час Другої світової війни. В Ізраїлі Німеччину називають кращим другом і союзником. У Польщі, країні, якій німці принесли стільки страждань, міністр закордонних справ закликає Німеччину проявити більше мужності в політичній діяльності й не боятися займати більш владні позиції. А США вже давно очікують, що Німеччина стане активнішою на світовій політичній арені.

Німеччина все більше намагається впливати на події у світі, наприклад, після референдуму в Великій Британії про вихід з Євросоюзу саме Німеччина спільно з Францією опублікувала документ «Сильна Європа в небезпечному 
світі», основна ідея якого полягає в необхідності посилення інтеграційних зусиль країн, у сфері безпеки також.

Сьогодні найкраще у світі ставляться до Німеччини. Згідно з опитуванням громадської думки, проведеним для BBC World Service, позитивно вплив країни оцінили понад 59 \% респондентів. В усьому світі німців вважають працездатними, дисциплінованими, добре організованими та продуктивними, інтерес до Німеччини і німців зростає.

Нині Німеччина має одне з найпривабливіших у світі міжнародних іміджів, що підтверджують, зокрема, опитування громадської думки та соціологічні дослідження як в самій ФРН, так і в інших країнах. Такий результат досягнутий передусім завдяки спеціально організованій, цілеспрямованій і систематичній діяльності.

\section{References:}

1. Akayomova, A. (2010). Osoblyvosti imidzhu yak skladovoyi politychnoho marketynhu [Features of image as a component of political marketing]. Politychnyy menedzhment [Political management], no. 1, p. 54.

2. Brown, L. (2001). Imidzh - put' $k$ uspekhu [Image - the road to success], SPb: Ed. Peter House, pp. 5-17.

3. Danilov, V. (2009). Osoblyvosti formuvannya politychnoho imidzhu derzhavy [Features of forming the political image of the state]. Politychnyy menedzhment [Political management], no. 2, pp. 18-24.

4. Nimechchyna - yevropeyske opudalo? [Germany - European Scarecrow?]. (2019). Available at: http://www.dw.de/Germany - European - Scarecrow.

5. Hakke, K. (1995). Velyka derzhava mymovoli (zovnishnya polityka FRN) [TheGreat Power inadvertently (foreign policy of Germany)]. Moscow, pp. 217-220.

6. Lavrynenko, G. (2011). Formuvannya mizhnarodnoho imidzhu Ukrayiny v zakhidnomu sviti (na prykladi Polshchi) [Formation of the international image of Ukraine in the Western world (on the example of Poland)]. Politolohiya [Political Science], no. 4, pp. 48-64.

7. Pavlov, N. (1998). Zovnishnya polityka FRN: kontseptsiyi ta realiyi 80-kh rokiv [Germany's foreign policy: concepts and realities of the 80's]. International Politics, Moscow, p. 227.

8. Pavlov, N. (2006). Istoriya suchasnoyi Nimechchyny, 1945-2005 [History of Modern Germany, 1945-2005]. Moscow.

9. Patrushev, A. (2003). Nimetska istoriya [German history]. Moscow, Publishing House "All the World", p. 411.

10. Shevchenko, O. (2008). Teoretychni aspekty otsinyuvannya mizhnarodnoho brendu krayiny [Theoretical aspects of evaluation of the country's 
Міжнародні відносини: теоретико-практичні аспекти

Випуск 5 (2020)

ISSN (print) 2616-745X; ISSN (online) 2616-7794

international brand]. Aktualni problemy mizhnarodnykh vidnosyn [Current issues of international relations], isssue 79, part 1.

(C) Дзюба О. А., 2020 